\title{
Discovery of Pogonophora in warm shallow waters of the Florida Shelf
}

\author{
Eve C. Southward ${ }^{1} \&$ James K. Culter ${ }^{2}$ \\ ' Marine Biological Association, Citadel Hill, Plymouth PL1 2PB, United Kingdom \\ ${ }^{2}$ Mote Marine Laboratory, 1600 City Island Park, Sarasota, Florida 33577, USA
}

\begin{abstract}
A new small species of Siboglinum has been found in sediments of sub-tropical waters off southwest Florida, at 24 to $90 \mathrm{~m}$ depth, where bottom temperatures range from 17 to $26^{\circ} \mathrm{C}$. This is unexpectedly warm for a pogonophoran. The phylum in general is mostly deep sea except for a few species that reach shelf depths in cold boreal or arctic regions. The new find suggests Pogonophora may be more widely distributed than previously thought.
\end{abstract}

Pogonophora are predominantly deep-sea animals. In the tropics they have not previously been reported from less than $300 \mathrm{~m}$, seeming to be limited to subthermocline waters cooler than $10^{\circ} \mathrm{C}$ (Southward $1971 \mathrm{~b}, 1972$, Gureeva 1981). A few shallow water species have been found in Arctic shelf seas and in boreal stratified seas where bottom temperatures are low for most of the year (Southward 1971a, 1971b, 1979). The recently discovered giant vestimentiferan worms (Riftia pachyptila Jones 1980) from the Pacific at $2500 \mathrm{~m}$ are related to pogonophores, and their occurrence close to hydrothermal vents at first sight seemed to contradict the idea that pogonophores are restricted to cold water. However, it appears that these vestimentiferan worms live in places where the hot vent waters mix with cold bottom waters, and although a recent measurement suggests an upper limit of $35^{\circ} \mathrm{C}$, most of the vestimentiferans experience temperatures from 2 to $14^{\circ} \mathrm{C}$ (Desbruyères \& Laubier 1983, Hessler \& Smithey 1983, Canadian American Seamount Expedition 1985). It is notable that related vestimentiferans occur in a brine seep at the foot of the Florida Escarpment $\left(4.4^{\circ} \mathrm{C}\right)$ and in an oil-rich seep area on the Louisiana Slope, also in the Gulf of Mexico, at only $600 \mathrm{~m}$ depth with no indication of elevated temperatures (Paull et al. 1984, Brooks et al. 1985).

A clear exception to the 'cold-water rule' has now been discovered on the south-west Florida Shelf. A new small species of Siboglinum has been found quite widely distributed in a region where the bottom temperatures range from 17 to $26^{\circ} \mathrm{C}$. The Florida shelf pogonophore was found during a survey of the softbottom benthos by the Mote Marine Laboratory, sponsored by the United States Department of the Interior, Minerals Management Service. Thirty stations were sampled over the course of 6 cruises: Nov 1980, AprMay 1981, Jul-Aug 1981, Jan-Feb 1982, Dec 1982, May-Jun 1983 (Fig. 1). At each of 15 soft-bottom stations 5 samples were taken with a modified Reineck box corer $19 \times 30 \mathrm{~cm}, 30 \mathrm{~cm}$ deep. The top $15 \mathrm{~cm}$ of each core was washed through a $0.5 \mathrm{~mm}$ sieve and the residue preserved in formalin for later sorting in the laboratory (Woodward-Clyde Consultants 1983a, b).

Pogonophores were found at 8 stations sampled during Cruises I, II and IV. They were most common at Station 8 , where there were $45 \mathrm{~m}^{-2}$ in 1980 . These pogonophores have a single tentacle, which shows that they probably belong to the genus Siboglinum. They live in colourless, transparent tubes not wider than $0.2 \mathrm{~mm}$ and about $40 \mathrm{~mm}$ long. The presence of mature females, incubating embryos, shows that the population is adult and not merely a sporadic settlement of juveniles from some deep-water population. These pogonophores belong to a new species not closely related to other species known from nearby deepwater habitats (Ivanov 1971, Southward 1971b, 1972, Gureeva 1981).

The stations at which pogonophores were found were fairly widely distributed in the mid-shelf region, with 6 stations at 38 to $58 \mathrm{~m}, 1$ at $24 \mathrm{~m}$ and 1 at $90 \mathrm{~m}$. At most of these the sediment was fine or medium sand, but at Station 26 it was a carbonate ooze of silt/clay sized particles. The $\mathrm{CaCO}_{3}$ content exceeded $90 \%$ at all except Station 2, where it was $42.5 \%$. The occurrence of macroalgae indicated that the range of depths occupied by the pogonophores was within the euphotic 


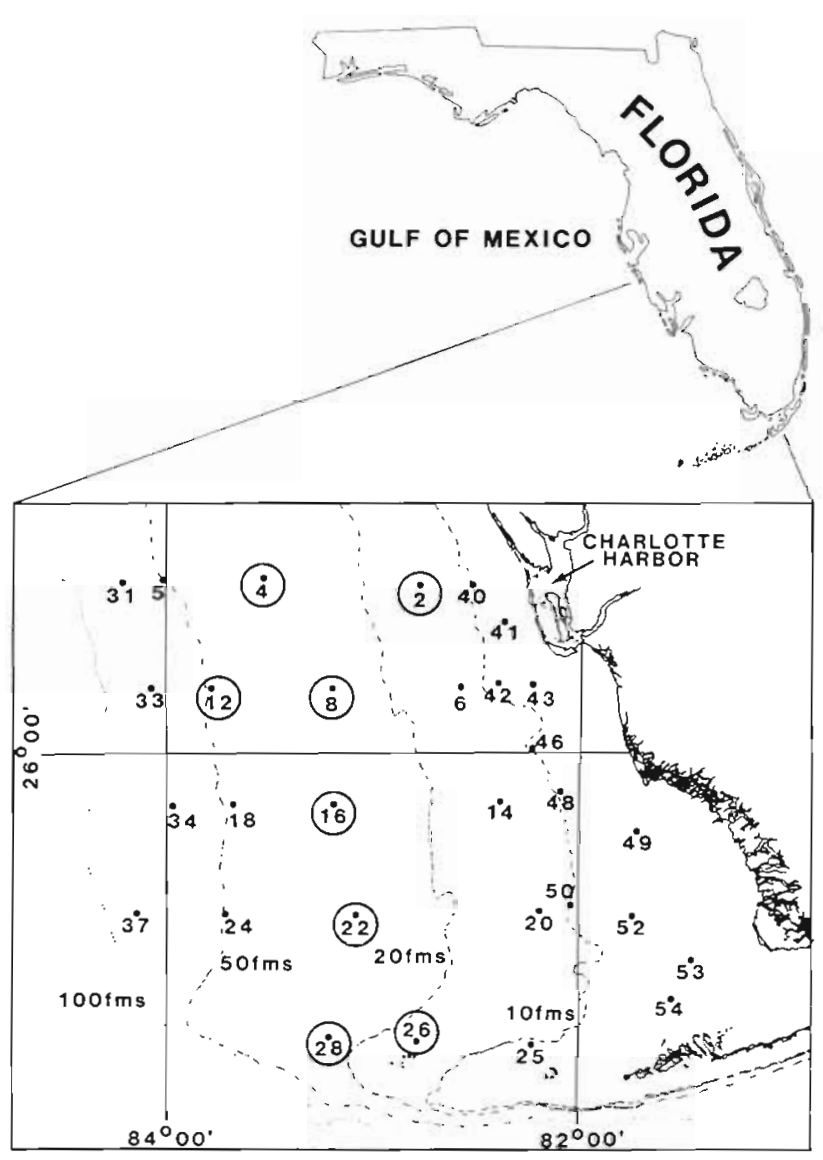

Fig. 1. The southwest Florida Shelf with station numbers. Circles show presence of Pogonophora. Depths in fathoms $(1 \mathrm{fm}=1.83 \mathrm{~m})$

zone, another unusual situation for the phylum. Epifauna was scarce. The infauna was dominated by polychaetes (46 to $48 \%$ of macrofaunal individuals counted. At Station 8, where there were 45 Siboglinum $\mathrm{m}^{-2}$, the total macrofauna amounted to 4,385 individuals $\mathrm{m}^{-2}$, so the pogonophores formed a rather small proportion of the fauna. The water temperatures measured near the bottom in November ranged from 17.3 to $26^{\circ} \mathrm{C}$, while in April they were fairly uniform around $22^{\circ} \mathrm{C}$.

The new Siboglinum from the Florida Shelf will be described elsewhere. The preservation of the specimens is not good enough to confirm by sectioning whether they contain symbiotic bacteria such as have been found in Riftia and all small pogonophores examined (Cavanaugh et al. 1981. Southward 1982). As yet we have no data on the redox potential or sulphide content of the sediments. A lucinacean bivalve, Lucina nassula Conrad, was present at many of the pogonophore stations. Lucinaceans are common in reducing sediments (Allen 1958), and many of them, including $L$. nassula, harbour symbiotic bacteria in their gills; at least some of these gill symbionts can use sulphide as an energy source to fix carbon dioxide autotrophically, and carbon isotope data suggests they form a major source of nutrition for the bivalves (Felbeck et al. 1981, Cavanaugh 1983, Berg \& Alatolo 1984, Fisher \& Hand 1984, Dando et al. 1985, 1986, Schweimanns \& Felbeck 1985, Spiro et al. 1986). Hence we believe that the new warm-water Siboglinum will resemble boreal shallow water pogonophores that have been examined biochemically, and will be found to be dependent on sulphideoxidising symbionts for its nutrition (Southward et al. 1986).

The presence of sulphide or another reduced compound capable of being used as an energy source by symbiotic bacteria (Jannasch 1985) is probably an essential habitat requirement for pogonophores. However, there must be other factors controlling their distribution in shelf seas. Temperature may be important for many species, but the new find suggests that temperature does not control the group as a whole. The Florida Shelf pogonophores are small, and a minor element of the biomass. They might be overlooked in other sampling programmes, especially when oligochaetes and polychaetes are abundant. Future investigators should be alert to the possibility that pogonophores may occur in shelf sediments in both temperate and tropical regions.

Acknowledgements. Collections for this research were part of an environmental baseline study sponsored by the U.S. Department of the Interior, Minerals Management Service.

\section{LITERATURE CITED}

Allen, J. A. (1958). On the basic form and adaptations to habitat in the Lucinacea (Eulamellibranchia). Phil. Trans R. Soc. B 241: 421-484

Berg, C. J., Alatolo, P. (1984). Potential of chemosynthesis in molluscan mariculture. Aquaculture 39: 165-179

Brooks, J. M., Kennicutt, M. C., Bidigare, R. R., Fay, R. A (1985). Hydrates, oil seepage, and chemosynthetic ecosystems on the Gulf of Mexico Slope. EOS (Trans. Am. geophys. Un.) 66: 106

Canadian American Seamount Expedition (1985). Hydrothermal vents on an axis seamount of the Juan de Fuca Ridge. Nature, Lond. 313: 212-214

Cavanaugh, C. M. (1983). Symbiotic chemoautotrophic bacteria in marine invertebrates from sulphide-rich habitats. Nature, Lond. 302: 58-61

Cavanaugh, C. M., Gardiner, S. L., Jones, M. L., Jannasch, H. W., Waterbury, J. B. (1981). Prokaryotic cells in the hydrothermal vent tube worm Riftia pachyptila Jones: possible chemoautotrophic symbionts. Science 213: 320-342

Dando, P. R., Southward, A. J., Southward, E. C., Terwilliger, N. B., Terwilliger, R. C. (1985). Sulphur-oxidising bacteria and haemoglobin in gills of the bivalve mollusc Myrtea spinifera. Mar. Ecol. Progr. Ser 23: 85-98

Dando, P. R., Southward, A. J., Southward, E. C. (1986) Chemoautotrophic symbionts in the gills of the bivalve 
mollusc Lucinoma borealis and the sediment chemistry of its habitat. Proc. R. Soc. (B) (in press)

Desbruyères, D., Laubier, L. (1983). Primary consumers from hydrothermal vents animal communities. In: Rona, P. A., Bostrom, K., Laubier, L., Smith, K. L. (ed.) Hydrothermal processes at seafloor spreading centers. Plenum Press, New York, London, p. 711-734

Felbeck, H., Childress, J. J., Somero, G. N. (1981). CalvinBenson cycle and sulphide oxidation enzymes in animals from sulphide-rich habitats. Nature, Lond. 293: 291-293

Fisher, M. R., Hand, S. C. (1984). Chemoautotrophic symbionts in the bivalve Lucina floridana from seagrass beds. Biol. Bull. mar biol. Lab., Woods Hole 167: 455-459

Gureeva, M. A. (1981). Pogonophora of the Caribbean Sea (material from the 14th cruise of the R/V Akademik Kurchatov'. Trudy Inst. Okeanol. 115: 183-194 (in Russian)

Hessler, R. R., Smithey, W. M. (1983). The distribution and community structure of megafauna at the Galapagos Rift hydrothermal vents. In: Rona, P. A., Bostrom, K., Laubier, L., Smith, K. L. (ed.) Hydrothermal processes at seafloor spreading centers. Plenum Press, New York, London, p. $735-770$

Ivanov, A. V. (1971). New Pogonophora from the Atlantic and Pacific Oceans. J. Zool., Lond. 164: 271-304

Jannasch, H. W (1985). The chemosynthetic support of life and the microbial diversity at deep-sea hydrothermal vents. Proc. R. Soc. (B) 225: 277-297

Paull, C. K., Hecker, B., Commeau, R, Freeman-Lynde, R. P., Neumann, C., Corso, W. P., Golubic, S., Hook, J. E., Sikes, E., Curray, J. (1984). Biological communities at the Florida Escarpment resemble hydrothermal vent taxa. Science 226: 965-967

Schweimanns, M., Felbeck, H. (1985). Significance of the occurrence of chemoautotrophic bacterial endosymbionts in Jucinid clams from Bermuda. Mar. Ecol. Prog. Ser. 24: $113-120$
Southward, A. J., Southward, E. C., Dando, P. R., Barrett, R. L,, Ling, R. (1986). Chemoautotrophic function of bacterial symbionts in small Pogonophora. J. mar. biol. Ass. U.K. 66: in press

Southward, E. C. (1971a). Recent researches on the Pogonophora. Oceanogr. mar. Biol. A. Rev. 9: 193-220

Southward, E. C. (1971b). Pogonophora of the northwest Atlantic: Nova Scotia to Florida. Smithson. Contr. Zool. 88: $1-29$

Southward, E. C. (1972). On some Pogonophora from the Caribbean and the Gulf of Mexico. Bull. mar. Sci. 22: 739-776

Southward, E. C. (1979). Horizontal and vertical distribution of Pogonophora in the Atlantic Ocean. Sarsia 64: 51-55

Southward, E. C. (1982). Bacterial symbionts in Pogonophora. J. mar. biol. Ass. U.K. 62: 889-906

Spiro, B., Greenwood, P. B., Southward, A. J., Dando, P. R. $(1986) .{ }^{13} \mathrm{C} /{ }^{12} \mathrm{C}$ ratios in marine invertebrates from reducing sediments: confirmation of nutritional importance of chemoautotrophic endosymbiotic bacteria. Mar. Ecol. Prog. Ser. 28: 233-240

Woodward-Clyde Consultants and Continental Shelf Associates, Inc. (1983a). Southwest Florida Shelf ecosystems study-year 1. Final Report and 2 Appendices. Prepared for U.S. Department of the Interior, Minerals Management Service, Metaire, LA. Contract 14-12-0001-29142

Woodward-Clyde Consultants and Continental Shelf Associates, Inc. (1983b). Southwest Florida Shelf ecosystems study-year 2. Final Report and 2 Appendices. Prepared for U.S. Department of the Interior, Minerals Management Service, Metaire, LA. Contract 14-12-0001-29036

Accepted for printing on November 7, 1985 